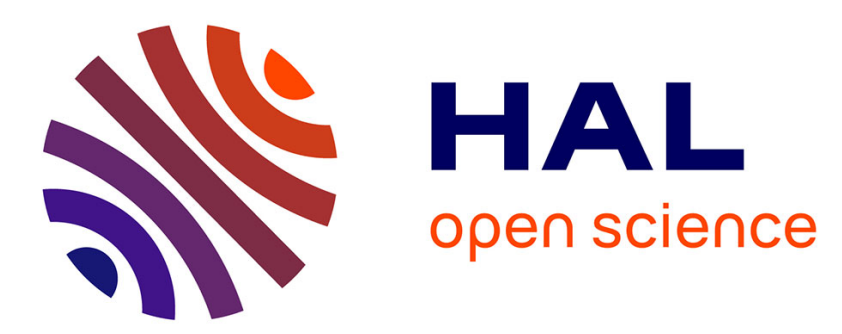

\title{
Therapeutic approaches in young women with advanced or metastatic breast cancer
}

Andrés García Palomo

\section{To cite this version:}

Andrés García Palomo. Therapeutic approaches in young women with advanced or metastatic breast cancer. Breast Cancer Research and Treatment, 2010, 123 (s1), pp.49-52. 10.1007/s10549-010-10710 . hal-00565562

\section{HAL Id: hal-00565562 https://hal.science/hal-00565562}

Submitted on 14 Feb 2011

HAL is a multi-disciplinary open access archive for the deposit and dissemination of scientific research documents, whether they are published or not. The documents may come from teaching and research institutions in France or abroad, or from public or private research centers.
L'archive ouverte pluridisciplinaire HAL, est destinée au dépôt et à la diffusion de documents scientifiques de niveau recherche, publiés ou non, émanant des établissements d'enseignement et de recherche français ou étrangers, des laboratoires publics ou privés. 
Manuscript Type: Brief article

\section{Therapeutic approaches in young women with advanced or metastatic breast cancer}

Andrés García Palomo ${ }^{1}$

${ }^{1}$ Hospital de León, León, Spain.

Corresponding author:

Andrés García Palomo, MD

Department of Medical Oncology

Hospital de León

Calle Altos de Nava, S/N.

24701-León. Spain

E-mail: $\quad$ agarciapalomo@gmail.com

Phone: $\quad$ +34 987237400

Fax: $\quad+34987233322$ 


\section{Introduction}

Advanced breast cancer is a chronic disease with a remarkably heterogeneous clinical picture and a mean survival of 2 to 4 years [1]. Treatment goals are to increase overall survival and disease-free survival, and improve quality of life [2]. The inclusion of novel targeted therapies in recent years has brought renewed hope for the possibility of improving these goals, and has broadened the spectrum of therapeutic choic es.

Prognostic and predictive factors for early disease differ from those of advanced disease. In spite of this, many therapeutic decisions in young women with advanced breast cancer are based on predictive characteristics of early breast cancer. There is evidence demonstrating that approximately $20 \%$ of metastatic or relapsed tumors undergo changes in the expression of either hormone receptors or human epidermal growth factor receptor-2 (HER-2)/neu in comparison to the primary tumor [3]. Although methodological reasons might be behind some of the discordances in results, true biological changes in the clinical phenotype cannot be completely excluded. At any rate, the discordance in pathology and molecular markers between primary and metastatic tumors seen in breast cancer may have a negative impact on overall survival because of inadequate use of the available therapies [4].

In early beast cancer, young age per se at diagnosis is universally considered a negative prognostic factor, but this does not seem to translate to women with advanced breast cancer [5]. However, breast tumors in women under 40 are more likely to be associated with high-risk tumor features and poorer prognosis [6], and therefore, in the setting of metastatic breast cancer, younger age could be considered an additional factor of worse prognosis. Until specific markers of metastatic breast cancer in young women are identified, therapeutic options in this age group remain the same as for older women, i.e. endocrine therapy, chemotherapy, targeted therapy, or a combination of the three. 


\section{Endocrine therapy}

Endocrine therapy is indicated in young women with luminal-type tumors, low tumor burden, no visceral involvement, slow progression, long disease-free intervals and a history of sensitivity to endocrine treatments.

The vast majority of women under 40 years are premenopausal. Therefore, as in early breast cancer, in advanced breast cancer the abolition or suppression of ovarian function is the primary objective [7]. Currently, the best therapeutic option for this purpose is the use of luteinizing hormone-releasing hormone (LHRH) agonists, either alone or in combination with tamoxifen, although the latter option is significantly better in terms of overall survival and progression-free survival than an LHRH agonist alone [8].

Currently, there is insufficient data to support the use of aromatase inhibitors (Al) in premenopausal women with early breast. Nevertheless, in metastatic breast cancer, preliminary data from Agrawal et al [9] on 36 premenopausal patients (median age 44 years) showed that treatment with goserelin plus anastrozole produced sustained clinical benefit and minimal side effects in premenopausal women with estrogen receptor (ER)-positive advanced breast cancer.

On the other hand, treatment recommendations in young postmenopausal women are as follows:

- In women who have not received prior endocrine therapy, Als are the treatment of choice [10]. There is evidence suggesting that letrozol may be more active than anastrozole in metastatic breast cancer as second-line therapy [11].

- In women who have received prior treatment with tamoxifen, second-line treatment choices include Als and the selective estrogen receptor down-regulator fulvestrant. Both therapies have been shown to be equally effective, although fulvestrant is associated with a significantly lower incidence of joint disorders compared 
with anastrozole and seems to produce a non-significant increase in time to progression $[12,13]$.

- In women previously treated with Als, and who have remained amenorrheic, second-line treatment could involve the use of fulvestrant, or a non-steroidal Al (such as anastrozole) if prior treatment involved a steroidal Al (such as exemestane), and vice versa; i.e. a steroidal $\mathrm{Al}$ if prior treatment involved a non-steroidal $\mathrm{Al}$ [14].

\section{Chemotherapy}

Chemotherapy is indicated in young women with triple- and HER-2-negative tumors, luminal-type tumors refractory to endocrine therapy, and in rapidly progressive disease or high tumor burden, regardless of phenotype.

Therapeutic recommendations for young premenopausal women regarding adjuvant chemotherapy are the same as for older women. However, the fact that a larger proportion of young women are HER-2 positive, hormone receptor negative, and tolerate better chemotherapy than their older counterparts may have a bearing on the type of regimen used.

In patients without prior treatment, anthracyclines and taxanes followed by vinorelbine, gemcitabine and capecitabine are currently the most active agents for advanced breast cancer according to the 'Third Consensus on Medical Treatment of Metastatic Breast Cancer' [15]. A large body of evidence has shown that the combination of anthracyclines and taxanes is superior to the use of either drug alone [15].

In patients with recurrent disease and prior anthracycline therapy, gemcitabine in combination with paclitaxel, and capecitabine in combination with docetaxel, were shown to be superior to the use of taxanes alone $[16,17]$. However, none of these studies separately analyzed patients younger than 40 years of age; therefore, it is not known whether there are significant differences in terms or efficacy or toxicity in this subgroup of patients. 
Triple-negative breast cancer, defined as the absence of endocrine and HER-2 receptor expression, deserves to be mentioned separately, because of its high prevalence in advanced breast cancer and in women under 40 years [18].

At present, no specific recommendations can be made for young premenopausal women, but data collected from trials with neoadjuvant chemotherapy have yielded interesting findings. Importantly, women with triple-negative tumors respond extremely well to chemotherapy, especially to taxanes, platinum-based cytotoxics and anthracyclines, as well as to high-dose regimens $[19,20]$, however survival rate in nonresponders is short.

\section{Targeted therapies}

The identification of specific cellular receptors has encouraged the search for molecules aimed at specific molecular targets, such as the intracellular and extracellular domains of HER (trastuzumab, gefitinib or erlotinib) and the vascular endothelial growth factor [21].

To date, the three agents approved for the treatment of advanced breast cancer are trastuzumab, lapatinib and bevacizumab.

\section{Trastuzumab}

In combination with paclitaxel, trastuzumab is indicated for the first-line treatment of HER-2 overexpressing metastatic breast cancer or as monotherapy for the treatment of HER-2 overexpressing breast cancer in patients who have received one or more chemotherapy regimens for metastatic disease (http://www.accessdata.fda.gov/drugsatfda docs/label/2008/022059s004lbl.pdf).

The mechanism of action of trastuzumab is not fully understood, but may involve inhibition of HER-2 cleavage and shedding, induction of HER-2 gene expression, inhibition of the PI3K pathway and/or inhibition of angiogenesis [22]. 
The pivotal trial by Slamon et al [23] demonstrated that the addition of trastuzumab to chemotherapy was associated with a significantly longer time to progression, higher rates of objective response, longer duration of response, lower mortality at 1 year, longer survival and a $20 \%$ reduction in the risk of death in women with metastatic breast cancer overexpressing HER-2. Unfortunately, there are no specific data on women under 40 years, but the fact that younger women tend to have a greater expression of HER-2 than their older counterparts can give us an indication of the benefits this targeted therapy may offer young women with advanced breast cancer.

\section{Lapatinib}

In combination with capecitabine, lapatinib is indicated for the treatment of patients with advanced or metastatic breast cancer whose tumors overexpress HER-2 and who have received prior therapy including an anthracycline, a taxane and trastuzumab (http://www.accessdata.fda.gov/drugsatfda docs/label/2007/022059s002lbl.pdf).

Lapatinib produces a reversible and selective inhibition of HER-1 and HER-2 tyrosine kinases [24]. Lapatinib in combination with capecitabine was superior to capecitabine alone in terms of time to progression in women with HER-2 advanced breast cancer that had progressed after treatment with anthracycline, taxane or trastuzumab-based regimens [25]. Again, there are no specific data for women younger than 40 years.

\section{Bevacizumab}

In combination with paclitaxel, bevacizumab is indicated for the treatment of patients who have not received chemotherapy for metastatic HER-2-negative breast cancer (http://www.accessdata.fda.gov/drugsatfda docs/label/2009/125085s0168lbl.pdf).

Bevacizumab is a humanized monoclonal antibody that recognizes and neutralizes all major isoforms of VEGF, preventing receptor binding and inhibiting endothelial cell proliferation and vessel formation [26]. 
In a phase III trial, bevacizumab plus paclitaxel significantly prolonged progression-free survival compared with paclitaxel alone and increased the objective response rate. The overall survival rate, however, was similar in the two groups. Importantly, a subgroup analysis showed an additional benefit in patients under 49 years and those with triple negative disease [27].

\section{Conclusions}

Advanced breast tumors in young women are more likely to be associated with high risk features, such as hormone receptor negativity, increased HER-2 expression and triple negative disease. Unfortunately, specific data on the epidemiology and treatment of women younger than 40 years is almost nonexistent, and therefore, to date treatment of these women does not differ from the treatment of older women, being endocrine therapy, chemotherapy, targeted therapy, or a combination of the three. Current endocrine treatment on young premenopausal women relies on the administration of LHRH agonists. In relation to chemotherapy, in patients without prior treatment, anthracyclines and taxanes followed by vinorelbine, gemcitabine and capecitabine are currently the most active agents. Regarding targeted therapies, the three agents currently approved for the treatment of advanced breast cancer are trastuzumab, lapatinib and bevacizumab. 


\section{Acknowledgments}

The authors acknowledge the support of Pfizer Spain, which facilitated the necessary meetings to evaluate and discuss all the data presented in this review, and Dr. Ximena Alvira from HealthCo SL (Madrid, Spain) for assistance in the preparation of this manuscript. 


\section{References}

1. Cardoso F, Di LA, Lohrisch C, Bernard C, Ferreira F, Piccart MJ (2002) Second and subsequent lines of chemotherapy for metastatic breast cancer: what did we learn in the last two decades? Ann Oncol 13:(2):197-207

2. Orlando L, Colleoni M, Fedele P, Cusmai A, Rizzo P, D'Amico M, et al. (2007) Management of advanced breast cancer. Ann Oncol 18 Suppl 6:vi74-6

3. MacFarlane R, Speers C, Masoudi H, Chia S (2008) Molecular changes in the primary breast cancer versus the relapsed/metastatic lesion from a large population-based database and tissue microarray series. ASCO Meeting Abstracts 26:(suppl 15):1000-

4. Liedtke C, Broglio K, Moulder S, Hsu L, Kau SW, Symmans WF, et al. (2009) Prognostic impact of discordance between triple-receptor measurements in primary and recurrent breast cancer. Ann Oncol

5. Largillier R, Ferrero JM, Doyen J, Barriere J, Namer M, Mari V, et al. (2008) Prognostic factors in 1,038 women with metastatic breast cancer. Ann Oncol 19:(12):2012-9

6. Peppercorn J (2009) Breast cancer in women under 40. Oncology (Williston Park) 23:(6):465-74

7. (2007) Ovarian ablation or suppression in premenopausal early breast cancer: results from the international adjuvant breast cancer ovarian ablation or suppression randomized trial. J Natl Cancer Inst 99:(7):516-25

8. Klijn JG, Blamey RW, Boccardo F, Tominaga T, Duchateau L, Sylvester R (2001) Combined tamoxifen and luteinizing hormone-releasing hormone (LHRH) agonist versus LHRH agonist alone in premenopausal advanced breast cancer: a meta-analysis of four randomized trials. J Clin Oncol 19:(2):343-53

9. Agrawal A, Winterbottom L, Robertson JF, Cheung KL (2008) Goserelin plus anastrozole $(G+A)$ as first-line systemic therapy for premenopausal estrogen 
receptor positive $(E R+)$ advanced breast cancer $(A B C)$-- clinical and endocrine data. ASCO Meeting Abstracts 26:(15_suppl):1091-

10. Mauri D, Pavlidis N, Polyzos NP, loannidis JP (2006) Survival with aromatase inhibitors and inactivators versus standard hormonal therapy in advanced breast cancer: meta-analysis. J Natl Cancer Inst 98:(18):1285-91

11. Rose C, Vtoraya O, Pluzanska A, Davidson N, Gershanovich M, Thomas R, et al. (2003) An open randomised trial of second-line endocrine therapy in advanced breast cancer. Comparison of the aromatase inhibitors letrozole and anastrozole. Eur J Cancer 39:(16):2318-27

12. Robertson JF, Osborne CK, Howell A, Jones SE, Mauriac L, Ellis M, et al. (2003) Fulvestrant versus anastrozole for the treatment of advanced breast carcinoma in postmenopausal women: a prospective combined analysis of two multicenter trials. Cancer 98:(2):229-38

13. Howell A, Pippen J, Elledge RM, Mauriac L, Vergote I, Jones SE, et al. (2005) Fulvestrant versus anastrozole for the treatment of advanced breast carcinoma: a prospectively planned combined survival analysis of two multicenter trials. Cancer 104:(2):236-9

14. Chia S, Gradishar W, Mauriac L, Bines J, Amant F, Federico M, et al. (2008) Double-blind, randomized placebo controlled trial of fulvestrant compared with exemestane after prior nonsteroidal aromatase inhibitor therapy in postmenopausal women with hormone receptor-positive, advanced breast cancer: results from EFECT. J Clin Oncol 26:(10):1664-70

15. Beslija S, Bonneterre J, Burstein HJ, Cocquyt V, Gnant M, Heinemann V, et al. (2009) Third consensus on medical treatment of metastatic breast cancer. Ann Oncol 20:(11):1771-85

16. O'Shaughnessy J, Miles D, Vukelja S, Moiseyenko V, Ayoub JP, Cervantes G, et al. (2002) Superior survival with capecitabine plus docetaxel combination 
therapy in anthracycline-pretreated patients with advanced breast cancer: phase III trial results. J Clin Oncol 20:(12):2812-23

17. Albain KS, Nag SM, Calderillo-Ruíz G, Jordaan JP, Llombart AC, Pluzanska A, et al. (2008) Gemcitabine plus Paclitaxel versus Paclitaxel monotherapy in patients with metastatic breast cancer and prior anthracycline treatment. J Clin Oncol 26:(24):3950-7

18. Stockmans G, Deraedt K, Wildiers H, Moerman P, Paridaens R (2008) Triplenegative breast cancer. Curr Opin Oncol 20:(6):614-20

19. Liedtke C, Mazouni C, Hess KR, Andre F, Tordai A, Mejia JA, et al. (2008) Response to neoadjuvant therapy and long-term survival in patients with triplenegative breast cancer. J Clin Oncol 26:(8):1275-81

20. Torrisi R, Colleoni M, Veronesi P, Rocca A, Peruzzotti G, Severi G, et al. (2007) Primary therapy with ECF in combination with a $\mathrm{GnRH}$ analog in premenopausal women with hormone receptor-positive T2-T4 breast cancer. Breast 16:(1):73-80

21. Fernández Y, Cueva J, Palomo AG, Ramos M, de Juan A, Calvo L, et al. (2009) Novel therapeutic approaches to the treatment of metastatic breast cancer. Cancer Treat Rev

22. Valabrega G, Montemurro F, Aglietta M (2007) Trastuzumab: mechanism of action, resistance and future perspectives in HER2-overexpressing breast cancer. Ann Oncol:mdl475

23. Slamon DJ, Leyland-Jones B, Shak S, Fuchs H, Paton V, Bajamonde A, et al. (2001) Use of chemotherapy plus a monoclonal antibody against HER2 for metastatic breast cancer that overexpresses HER2. N Engl J Med 344:(11):783-92

24. Reid A, Vidal L, Shaw H, de Bono J (2007) Dual inhibition of ErbB1 (EGFR/HER1) and ErbB2 (HER2/neu). Eur J Cancer 43:(3):481-9 
25. Geyer CE, Forster J, Lindquist D, Chan S, Romieu CG, Pienkowski T, et al. (2006) Lapatinib plus capecitabine for HER2-positive advanced breast cancer. N Engl J Med 355:(26):2733-43

26. Ferrara N, Hillan KJ, Gerber HP, Novotny W (2004) Discovery and development of bevacizumab, an anti-VEGF antibody for treating cancer. Nat Rev Drug Discov 3:(5):391-400

27. Miller K, Wang M, Gralow J, Dickler M, Cobleigh M, Perez EA, et al. (2007) Paclitaxel plus bevacizumab versus paclitaxel alone for metastatic breast cancer. N Engl J Med 357:(26):2666-76 